\title{
Landscape sociology as developing academic discipline
}

\author{
Madara Markova, Latvia University of Life Sciences and Technologies
}

\begin{abstract}
The common tendency in higher education is specialisation. Landscape has been subject of interest in sociology from its beginnings, and social aspects are one of mane characteristic parts of landscape. Even more - sociology is strong theoretical basis of landscape architecture. The research is made with aim to understand theoretical basis of landscape sociology as developing academic discipline. Methodology used in research is systematic literature review, which provides range of tools to identify connections in theory. Literature review was done to define landscape sociology as important academic discipline in higher education of landscape architecture. Landscape and sociology as academic disciplines have long history, but landscape sociology as separate discipline is still developing. It is important include landscape sociology in landscape architecture higher education.
\end{abstract}

Key words: landscape architecture, landscape sociology, specialisation

\section{Introduction}

Cultural anthropologists, historical geographers, landscape ecologists and environmental artists have contributed not only to the landscape architecture as academic discipline, but other disciplines as well. The European Political Strategy Centre has prepared information that shows tendencies in education. There are many challenges and goals to achieve; the most common in higher education is specialisation [10]. Landscape architecture is a multidisciplinary specialisation. Social aspect is an important part of landscape; it is of the same importance as the aspects of culture, nature, perception and aesthetics [25]. As scientists from various fields have confirmed, different society groups have direct connection with the landscape [11, 12, 23, 24].

Landscape, nature and environmental topics have been mentioned in sociology since its beginning. It is known that founders of the sociological field - Durkheim, Weber and Marx had all something to say about nature and society [15]. Landscape is developed and its construction has a social aspect. Especially nowadays when it becomes more and more important to make the surrounding environment in a way that it helps people to communicate and spend time outdoors. It must be created by considering both people and nature. Landscape architecture research as landscape itself is generally multi- or interdisciplinary and perhaps even trans-disciplinary [6]. Theoretical basis of landscape architecture comes from many disciplines. There are a few variations of defining the basis of landscape architecture research, one of them is this base being depicted as three overlapping value systems as shown in figure 2 [27]. From this point of view sociology is not just a part of landscape, but strong theoretical basis of theory and practice in landscape architecture.
Landscape architecture as academic discipline developed only in the early $20^{\text {th }}$ century. All the theoretical and academical roots come from the USA as the first higher education programme in landscape architecture was established in Harvard University, USA in 1990. Later this education developed also in Europe, originating in Agricultural University of Norway [31].

The aim of this research is to understand the theoretical basis of landscape sociology as a developing academic discipline. Systematic literature review methodology is used in landscape architecture and social sciences as it provides a range of tools to identify the theoretical connection [21, 29].

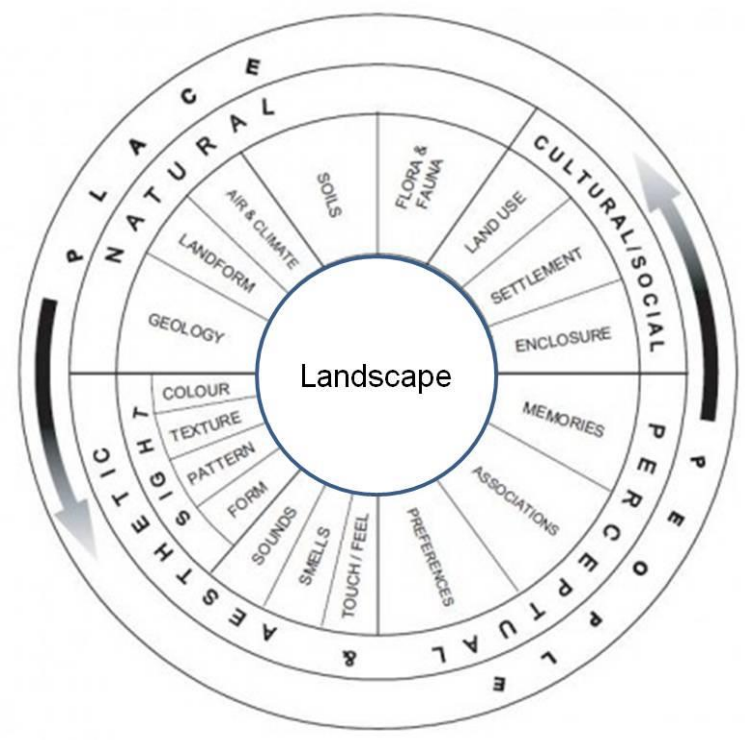

Fig. 1. What is landscape?

[Swanwick, C. Landscape Character Assessment. Guidance for England and Scotland. Edinburgh: The Countryside Agency, John Dower House, 84 p]. 


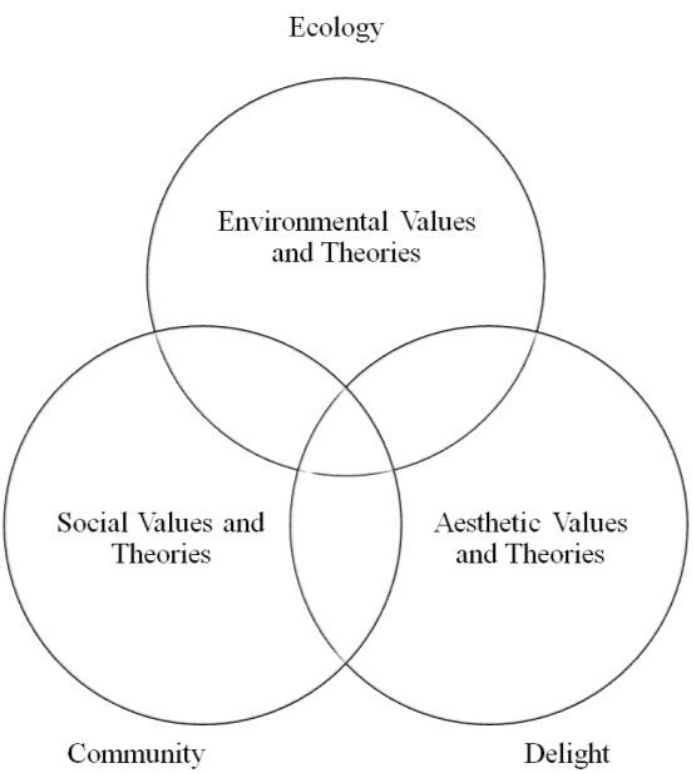

Fig. 2. Overlapping fields of value and sources of theory in landscape architecture [Thompson I. H. Ecology,

Community and Delight: Source of Value in Landscape Architecture. London: Spon Press, 2000, 216 p. ISBN-10: 9780419236108.].

\section{Materials and Methods}

The research is based on the literature review with the aim to define landscape sociology as an academic discipline important in higher education of landscape architecture. As a part of the research, also a study on landscape architecture study programmes for the study year 2017/2018 was conducted. The tasks of the research are as follows:

- to define landscape sociology as the origin and development of an academic discipline;

- to define similarities and differences in academic fields related to landscape sociology;

- to find out if landscape sociology is included as a subject in higher education study programmes of landscape architecture;

- to find out if sociology is mentioned as part of some study subjects in higher education study programmes of landscape architecture.

\section{Results and Discussion}

Results are divided into two parts - landscape sociology development and related fields, and landscape sociology in higher education.

\section{Landscape sociology development}

The first part of the term "landscape sociology" is the landscape itself. It is a comprehensive research subject. "Landscape" was mentioned for the first time in literature in 1598 [16]. Currently the landscape definition from the European Landscape Convention is widely used, which defines it as area, as perceived by people or visitors, whose character is the result of the action and interaction of natural and/or human factors [9]. Landscape research is done on wide range of different types [4].

If looking for the origins of landscape sociology, first, sociology development must be looked at. Sociology itself is the starting point of landscape sociology. Sociology is the science of human life in society. It explains both the functioning of different social structures (groups, communities, organizations) and the statistical groupings (e. g, gender, age, education, etc.), and the impact on the lives of individuals and society, as well as analysing, explaining and predicting changes in society. Sociology looks at the society as a system composed of different elements; it looks at the interaction of individuals among themselves and the surrounding social world. Sociology reveals the active role of the individual in explaining how it affects and transforms the surrounding social world and shows how social structures affect and form the individual [18].

Sociologists are interested in the experiences of individuals and how these experiences are shaped by interactions with society. Sociologists try to identify these general patterns by examining the behaviour of large groups of people living in the same society and landscape. Philosophers in the 18 th century created basic principles, which can be used in explaining social life. 1780 is the year when the word "sociology" appeared for the first time. As an academic subject, development of sociology in Europe started in 1895. Sociology can be divided into three parts: Structural Functionalism, Conflict Theory, and Symbolic Interactionism [19].

The beginning of the 20th century is the time when sociology appeared in Latvia in the form of public, political research, social philosophy and social statistics. However, only in the 1960s sociology developed as a separate branch of science. Initially it had to be proven why sociology had to be separated from philosophy and sociology (besides, the first academics were graduates of philosophy and with philosophical education) [28].

Landscape architecture has long history of development, but the title - landscape architect was used for the first time in 1858. It was used by Frederick Law Olmsted, one of the designers of Central Park in New York City. Throughout the 20th century the title - landscape architect - was used more frequently as landscape architecture became an established profession. Landscape architecture became a profession as it was requiring specific training and degrees [7]. Landscape is a subject of interest in many different fields and as a result the definition of it also differs. From the sociological point of view this definition includes two characteristics of landscape: landscape as a material objective and subjective culturally 


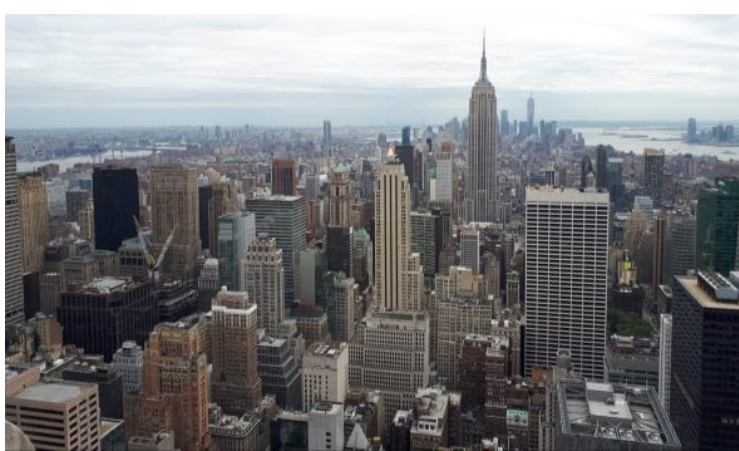

Fig. 3. New York - mixed-use planning [photo by the author, 2018].

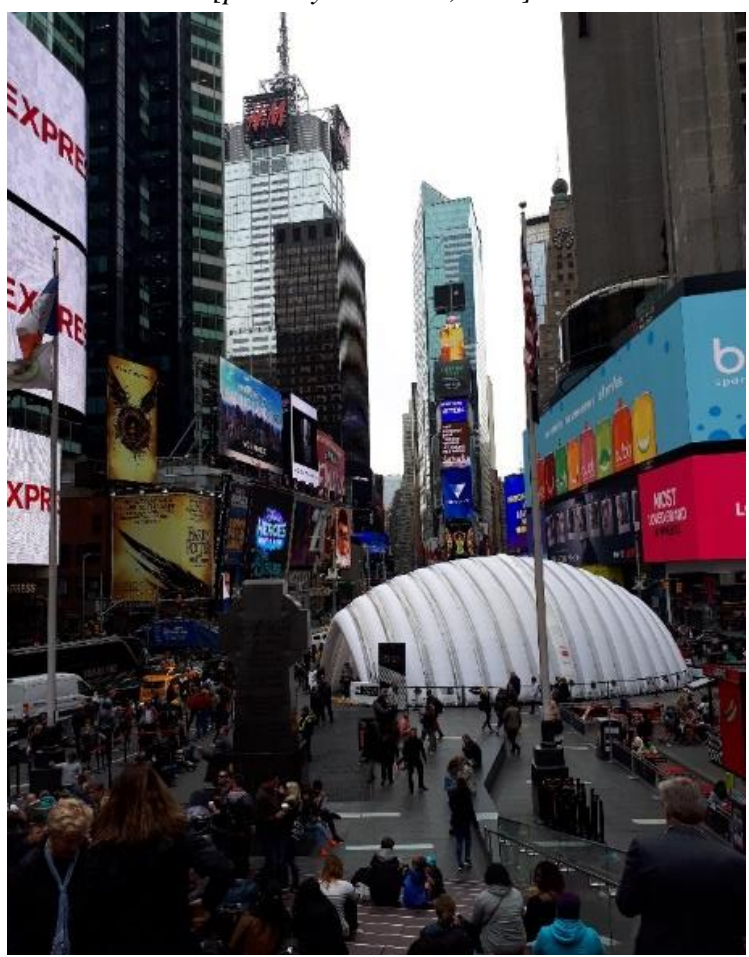

Fig. 4. New York-mixed-use planning [photo by the author, 2018].

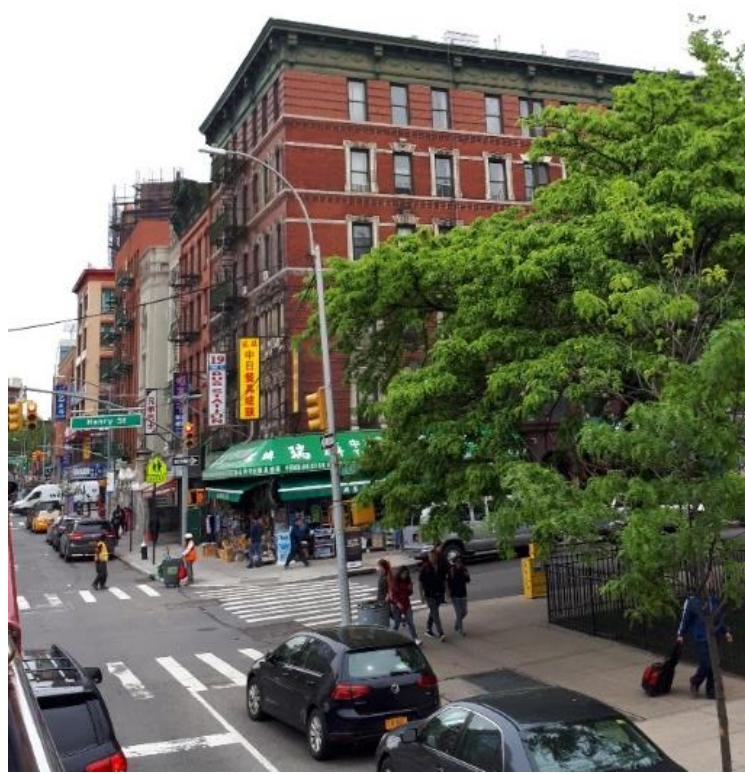

Fig. 5. New York-mixed-use planning [photo by the author, 2018]. determined form of perception and evaluation of this material structure [1].

Landscape architecture cannot be defined completely as it changes depending on the context. Landscape architecture theory is based on field practice [13]. Depending on the context the topic of landscape architecture could be - urban design, site planning, storm water management, urban planning, restoration, parks and recreation planning, green infrastructure planning, private or residential master planning design, etc.

Landscape architecture has practical changes in the field with the aim to make living of people together better from different point of views. One of the current tendencies in landscape architecture is mixed-use planning. It is influenced by the tendency to make multi-use living space in different scale. Mixed-use planning is closely connected to city's walkability. Mixed-use planning is the one, which includes a variety of land uses together in one area. This kind of space is supposed to be more vibrant and socially-interactive [3]. New York City is already quite multifunctional in the scale of each building, but still there are many challenges. Because of these new tendencies in landscape architecture, stronger research practice in landscape sociology and growing interaction in landscape and sociology interaction are developing.

Landscape sociology as a separate field of research is not well known. Landscape sociology researches social theory, social ecological systems, resilience studies, rural sociology, complexity science, interdisciplinary, landscape policy and planning, anthropology and natural resource management [8].

Landscape sociology differs from sociology, because the landscape aspect involves interaction between society and environment. If sociology looks at society as a system composed of different elements, then landscape sociology looks further how the society interacts with environment in some specific scale of landscape.

Landscape sociology includes different terms. From the social aspect, the idea that not only the residents of the exact place, but also its visitors and those who manage and develop the legislative frame of the landscape are of great importance. General legislation, exactly territorial planning documents, as well as development strategies are all parts of the legislative frame. The involved parties for each specific landscape site can vary - those can be municipalities, different municipality organisations, managers, government organisations. So far, the landscape sociology researchers have developed research capacities in social theory, social ecological systems, and resilience studies, rural sociology, complexity science, interdisciplinary, landscape policy and planning, anthropology and 


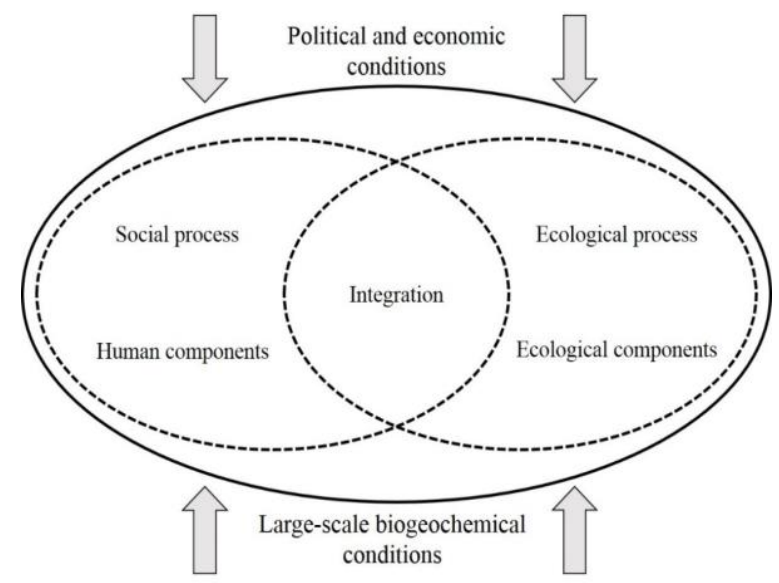

Fig. 6. Social-ecological system

[Virapongse, A., Brooks, S., Metcalf, C. E., Zedalise, M., Gosz

J., Andrew, A., Alessa L. A social-ecological systems approach for environmental management. Journal of Environmental Management, 2016, Vol. 178, p. 83-91].

natural resource management [8]. Landscape sociology also makes research on a never-ending cycle - social aspects define landscape and landscape defines identity [26]. Social networks are linked to the space in which they occur [22].

Some other point of view to terms landscape and sociology is that landscape is the place, where social and ecological systems meet. Social and ecological systems are two dimensions, which cannot be separated. In simple terms it is clear, that nature affects people and people affect nature [5].

Figure 6 generally shows the interaction of these social and ecological systems. Socioecological system is complex and includes social processes, human components as one part, and ecological process and ecological components as another part. Among these two parts there are integration-management practices, adaption and resource use. The integration part is the part of landscape architect's daily life. The landscape architect works the same way as the socio-ecological system, where political and economic conditions as for example the project's budget and development plans are found on the one side and large-scale biogeochemical conditions, which are important in the process of making choices about plants, materials and functional planning of the place, on the other side [32].

It is also important to mention other related research fields, e.g. human ecology and environmental sociology. Human ecology is similar to landscape sociology. Human ecology is a study of the interaction of humans with their environments. The main topics of human ecology are genetic, physiological, and social adaptation to the environment and to environmental change, role of social, cultural, and psychological factors in the maintenance or disruption of ecosystems, effects of population density on health, social organization, or environmental quality, new adaptive problems in urban environments, interrelations of technological and environmental changes [2, 17].

Environmental sociology formed in late 1970s. In a wider range it looks at the understanding of the relationship between the society and the environment. The most important task of environmental sociology in the 21 st century is to discover the most effective mechanism of environmental reform, which will guide the society to more socially secure and environmentally friendly arrangement. [15].

TABLE 1

Terms and Their Comparison. Created by the author.

\begin{tabular}{|c|c|c|c|}
\hline$\underset{\theta}{E}$ & 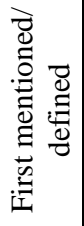 & 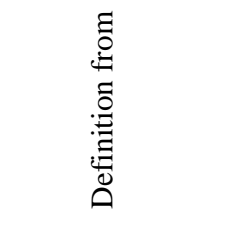 & 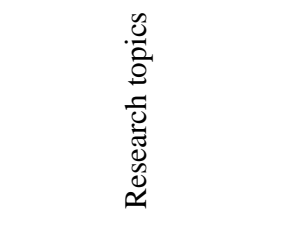 \\
\hline 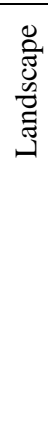 & $\begin{array}{l}\infty \\
\stackrel{2}{n}\end{array}$ & $\begin{array}{l}\text { The landscape } \\
\text { is a part of } \\
\text { the land, as } \\
\text { perceived by } \\
\text { local people or } \\
\text { visitors, which } \\
\text { evolves through } \\
\text { time as a result } \\
\text { of being acted } \\
\text { upon by natural } \\
\text { forces and } \\
\text { human beings. }\end{array}$ & $\begin{array}{l}\text { Due to the holistic } \\
\text { nature of this term, } \\
\text { there is a wide } \\
\text { range of landscape } \\
\text { researches. }\end{array}$ \\
\hline 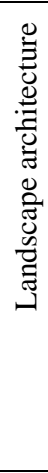 & $\begin{array}{l}\infty \\
\infty \\
\infty\end{array}$ & $\begin{array}{l}\text { Landscape } \\
\text { architecture is } \\
\text { a contextual } \\
\text { discipline. }\end{array}$ & $\begin{array}{l}\text { Urban design; } \\
\text { Site planning; } \\
\text { Storm water } \\
\text { Management; } \\
\text { Urban planning; } \\
\text { Restoration; } \\
\text { Parks and recreation } \\
\text { planning; } \\
\text { Green infrastructure } \\
\text { planning; } \\
\text { Private or residential } \\
\text { master planning and } \\
\text { design. }\end{array}$ \\
\hline $\begin{array}{l}30 \\
\frac{0}{0} \\
.0 \\
0 \\
0 \\
0\end{array}$ & $\stackrel{\infty}{\stackrel{\infty}{\beth}}$ & $\begin{array}{l}\text { Sociology looks } \\
\text { at society as a } \\
\text { system } \\
\text { composed of } \\
\text { different } \\
\text { elements, as } \\
\text { well as looks at } \\
\text { the interaction } \\
\text { of individuals } \\
\text { among } \\
\text { themselves and } \\
\text { the surrounding } \\
\text { social world. }\end{array}$ & $\begin{array}{l}\text { Experiences of } \\
\text { individuals; } \\
\text { How individual } \\
\text { experiences are } \\
\text { shaped by interactions } \\
\text { with society; } \\
\text { Identification of } \\
\text { general patterns by } \\
\text { examining the } \\
\text { behaviour of large } \\
\text { groups of people } \\
\text { living in the same } \\
\text { society, landscape. }\end{array}$ \\
\hline
\end{tabular}




\begin{tabular}{|c|c|c|c|}
\hline E्0 & 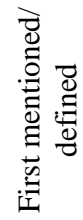 & 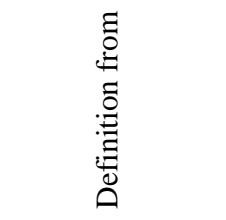 & 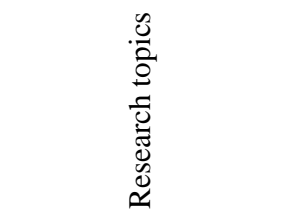 \\
\hline 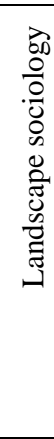 & $\begin{array}{l}\grave{\vdots} \\
\frac{0}{0} \\
\vdots \\
\vdots \\
\vdots \\
\vdots\end{array}$ & $\begin{array}{l}\text { Still in not } \\
\text { defined. }\end{array}$ & $\begin{array}{l}\text { Social theory; } \\
\text { Social ecological } \\
\text { systems; } \\
\text { Resilience studies; } \\
\text { Rural sociology; } \\
\text { Complexity science; } \\
\text { Interdisciplinary; } \\
\text { Landscape policy and } \\
\text { planning; } \\
\text { Anthropology; } \\
\text { Natural resource } \\
\text { management. }\end{array}$ \\
\hline 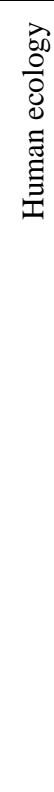 & $\frac{2}{2}$ & $\begin{array}{l}\text { Study of the } \\
\text { interaction of } \\
\text { humans with } \\
\text { their } \\
\text { environments. }\end{array}$ & $\begin{array}{l}\text { Genetic, } \\
\text { physiological, social } \\
\text { adaptation to the } \\
\text { environment; } \\
\text { Role of social, } \\
\text { cultural, and } \\
\text { psychological factors } \\
\text { in the maintenance or } \\
\text { disruption of } \\
\text { ecosystems; } \\
\text { Effects of population } \\
\text { density on health, } \\
\text { social organization, or } \\
\text { environmental } \\
\text { quality; } \\
\text { New adaptive } \\
\text { problems in urban } \\
\text { environments; } \\
\text { interrelations of } \\
\text { technological and } \\
\text { environmental } \\
\text { changes. }\end{array}$ \\
\hline 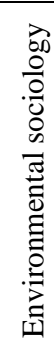 & 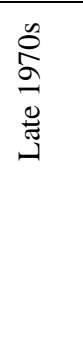 & $\begin{array}{l}\text { Relationship } \\
\text { between society } \\
\text { and the } \\
\text { environment. }\end{array}$ & $\begin{array}{l}\text { Discover the most } \\
\text { effective mechanism } \\
\text { of environmental } \\
\text { reform. }\end{array}$ \\
\hline
\end{tabular}

\section{Landscape sociology in higher education}

In most landscape architecture studies sociology is included in different subjects. After research on landscape architecture study programmes in different universities for the study year 2017/2018, it can be concluded that sociology as a topic is included in different subjects, but it is taught as a separate subject only in two universities - the Polytechnic University of Milan and Latvia University of Life Sciences and Technologies.
There are two universities, which have more research capacity in landscape sociology Melbourne School of Land and Environment and the Polytechnic University of Milan. In these two higher education institutions landscape sociology is a separate academic discipline.

There is a landscape sociology group in Melbourne School of Land and Environment. The Landscape and Environmental Sociology group has developed research practice capacities in such fields as social ecological systems, rural sociology, landscape policy and planning, natural resource management. These group members are involved in teaching such subjects as Reshaping Environments, Social Research Methods, Sustainable Landscapes and Building Resilient Settlements [30].

Sociology of the Environment is taught in the Polytechnic University of Milan. The main topics of the course include dimension and consequences of the urban mobility, transformation of the urban settlements and housing issues, urban social research, etc. Using the analytical tools and the major theory of the urban sociology, the course focuses on the social dynamics of the contemporary society and the major transformation. Course students gain knowledge and understanding of social sciences, social change and the principal trends in contemporary post-industrial societies [20].

In study year 2016/2017, Latvia University of Life Sciences and Technologies, Programme of Landscape Architecture underwent changes and introduced new subjects and methods for the bachelor and master studies. One of the new subjects is landscape sociology, which is introduced with the goal to have specialised subjects necessary for landscape architects while keeping wide and multidisciplinary knowledge in the study field. Landscape Sociology has been introduced as a new subject in bachelor studies of landscape architecture in Latvia University of Life Sciences and Technologies [14].

Learning outcomes of this study subject are:

- knowledge: structure, functioning and development of society in relation to landscape;

- practical skills: to work with various sources of information, to discuss the developing trends in society, and to critically evaluate socio-economic processes in the context of landscape architecture;

- competence: students are able to deal with problem situations and make decisions using social knowledge in professional activities of a landscape architect by using the results of various research findings. 


\section{Conclusion}

Landscape and sociology separately have long history from 16th and/to 18 th century respectively. Landscape sociology is a new and developing branch of sociology. Still the boundaries of landscape sociology and its definition are not clear. The most important difference between sociology and landscape sociology is the scale of landscape, which is important for landscape sociology. Many other similar terms in sociology are dedicated to landscape questions. It can be concluded that landscape and sociology both are wide and holistic terms.

Nowadays higher education becomes more and more specialised; therefore it is important to include landscape sociology in higher education studies of landscape architecture. Also it is important study subject as sociology is one of mane theoretical basis in landscape architecture.

\section{References}

1. Bell, S., Herlin I. S., Stiles, R. (eds.) Exploring the Boundaries of Landscape Architecture. 1st Edition. London: Routledge, 2011.334 p.

2. Bernard, L. L. Introductory Statement Regarding Human Ecology and Population. In: Publications of the American Sociological Society, Vol. XXIII, 1928, p. 30-34.

3. Beyer P. Mixed Use Zoning, from book Livable New York Resource Manual. [cited 28.03.2018.] http://www.aging.ny.gov/LivableNY/ResourceManual/Index.cfm

4. Bruns D., Van den Brink A., Tobi H., Bell S. Chapter 1: Advancing landscape architecture research. In: Research in landscape architecture: methods and methodology, Van den Brink A., Bruns, D., Tobi, H., Bell, S. (eds.). New York: Routledge, 2017, p. 11-23.

5. Conrad, E. Human and Social Dimensions of Landscape Stewardship. In: The Science and Practice of Landscape Stewardship. Bieling, C., Plieninger, T. (eds.). Cambridge University Press, 2017, p. 38-54.

6. Deming, E.M., Swafield, S. Landscape Architecture Research: Inquiry, Strategy, Design. Hoboken, NJ: John Wiley, 2011. 272 p. ISBN: 978-0-470-56417-2

7. Ejderyan, O. Landscape architecture. In: Encyclopaedia of environment and society, Robbins P. (ed.), 2007, Vol. 1, p. 1015-1016. Thousand Oaks, CA: SAGE Publications.

8. Eloma, U. E. Sociology of Landscape: Agricultural, Soil and Water Conservation in Calabar, Cross River State. In: Research on Humanities and Social Sciences, 2014, Vol. 4(11), p. 77-83. ISSN 2225-0484

9. European Landscape Convention. Council of Europe 2000 [cited 28.03.2019]. http://conventions.coe.int/Treaty /en/ Treaties/Html/176.htm

10. European Political Strategy Centre, 2017. 10 trends transforming education as we know it [cited 28.03.2019]. http://ec.europa.eu/epsc/sites/epsc/files/epsc_-_10_trends_transforming_education_as_we_know_it.pdf.

11. Gray, J. A rural sense of place: intimate experience in planning a countryside for life. In: Planning Theory and Practice, 2003, Vol. 4(1), p. 93-96.

12. Hay, R. A rooted sense of place in cross-cultural perspective. In: The Canadian Geographer, 1998, Vol. 42(3), p. 245-266.

13. Jørgensen, K. What is landscape architecture about? In: Scientific Journal of Latvia University of Agriculture Landscape Architecture and Art, 2015, Vol. 7(7), p. 46-49.

14. Latvia University of Life Sciences and Technologies Academic Education Bachelor's Study Programme "Landscape Architecture" (code 43581) Study Plan [cited 10.12.2018] http://www.llu.lv/sites/default/files/201801/Landsc\%20Arch_bak.pdf

15. Lockie, S. What is environmental sociology? In: Environmental Sociology, 2015, Vol. 1(3), p. 139-142, DOI: $10.1080 / 23251042.2015 .1066084$

16. Makhzoumi, J., Pungetti, G. Ecological Landscape Design and Planning, Spon Routledge, 1999 [cited 10.12.2018].

https://fcaib.edu.ng/books/Horticulture/\%5BJala_Makhzoumi\%5D_Ecological_Landscape_Design_and_P(BookFi.or g).pdf ISBN 0-203-27754-6

17. Marten, G. G. Human Ecology - Basic Concepts for Sustainable Development. London: Eathscan Publications, 2001. $256 \mathrm{p}$

18. National Encyclopaedia (Nacionālā enciklopēdija), Latvijas Nacionālā bibliotēka, 2018 [Latvian]

19. OpenStax College, Introduction to Sociology. OpenStax College, 2018 [cited 10.12.2018] https://cnx.org/contents/rQzKs1_@10.3:_97x1rAv@7/Introduction-to-Sociology

20. Polytechnic University of Milan, Sociology of the environment [cited 10.12.2018] https://www11.ceda.polimi.it/schedaincarico/schedaincarico/controller/scheda_pubblica/SchedaPublic.do?\&evn_defa ult $=$ evento\&c_classe $=692944 \& \_p j 0=0 \& \_p j 1=36 f e 1 f 3043 a a 6 b 803 e 30 a 70 d f 3 f 518 d 2$

21. Roe, M. Chapter 5: The challenges of publication. In: Research in landscape architecture: methods and methodology, Van den Brink A., Bruns D., Tobi H., Bell S. (eds.). New York, NY: Routledge, 2017, p. 65-84.

22. Saidi, T., de Villiers K., Douglas T. S., The sociology of space as a catalyst for innovation in the health sector. In: Social Science \& Medicine, 180, 2017, p. 36-44.

23. Stephenson, J. The cultural value model: an integrated approach to value in landscape. In: Landscape and Urban Planning, Amsterdam: Elsevier, No.84, 2008, p. 127-139.

24. Stokowski, P. Riches and Regrets: Betting on gambling in two Colorado mountain towns. Colorado: University Press of Colorado, 1996. $338 \mathrm{p}$. 
25. Swanwick, C. Landscape Character Assessment. Guidance for England and Scotland. Edinburgh: The Countryside Agency, John Dower House, 2002. 84 p.

26. Talen, E., Wheeler, S. M., Anselin, L. The social context of U.S. built landscape. In: Landscape and Urban Planning, 2018, Vol. 177, p. 266-280. [cited 10.12.2018] https://www.sciencedirect.com/science/article/pii/ S0169204618300744?via\%3Dihub

27. Thompson I.H. Ecology, Community and Delight: Source of Value in Landscape Architecture, London: Spon Press, 2000. 216 p. ISBN-10: 9780419236108.

28. Tisenkopfs T. Sociologija Latvijā (Sociology in Latvia). Rīga: LU Akadēmiskais apgāds, 2010. 536 p. [Latvian]

29. Tobi H., van den Brink A. Chapter 2: A process approach to research in landscape architecture. In: Research in landscape architecture: methods and methodology, Van den Brink A., Bruns D., Tobi H., Bell S. (eds). New York, NY: Routledge, 2017, p. 24-34.

30. University of Melbourne, Landscape and Environmental Sociology. [cited 10.12.2018] https://ecosystemforest. unimelb.edu.au/research/research-themes/environmental-social-science/landscape-and-environmental-sociolog

31. Van den Brink, A., Bruns, D., Bell, S., Tobi, H. Introduction. In: Research in landscape architecture: methods and methodology, Van den Brink A., Bruns D., Tobi H., Bell S. (eds.). New York, NY: Routledge, 2017, p. 1-9.

32. Virapongse A., Brooks S., Metcalf C. E., Zedalise M., Gosz J., Andrew A., Alessa L. A social-ecological systems approach for environmental management. In: Journal of Environmental Management, 2016, Vol. 178, p. 83-91.

INFORMATION ABOUT THE AUTHOR:

Madara Markova. Dr. arch., Assistant Professor at the Department of Landscape Architecture and Planning, Latvia University of Life Sciences and Technologies. Field of research: sacral landscape, cultural landscape and its elements, landscape sociology, teaching methods in landscape architecture field. E-mail: madara.markova@1lu.lv

Kopsavilkums. Kopējās tendences augstākajā izglītībā ir vērstas uz specializēšanos, tai skaitā arī Ainavu arhitektūras augstākajā izglīitibā. Ainava ir bijusi kā intereses un izpētes objekts sociolog̣ijā jau kopš tās pirmssākumiem. Un savukārt sociālais aspekts ir viens no raksturlielumiem ainavas izpētē un studijās. Sociālie aspekti ir tikpat nozīmīgi kā kultūra, daba, uztvere un estētika. Sociālie aspekti īpaši nozīmīgi kḷūst mūsdienās, kad nepieciešams veidot apkārtējo vidi tādā veidā, ka tā veicina vēlmi cilvēkiem komunicēt un pavadīt laiku ārtelpā. Ārtelpu jāveido, ņemot vērā gan cilvēkus un to vēlmes, gan dabu un tās nepieciešamības. Sociolog̣ija veido nozīmīgu teorētisko bāzi ainavu arhitektūras zinātnes nozarē un tās akadēmiskās disciplīnas attīstībā. Pētījums veikts ar mērḳi izprast teorētisko bāzi ainavu sociologijai kā akadēmiskajai disciplīnai, kas vēl tikai attīstās. Pētījumā izmantotā metodoloǵija ietver sistemātisku literatūras izpēti, kas sniedz dažādus rīkus sasaistes definēšanai teorijā. Literatūras izpēte veikta ar mērķi definēt ainavu sociologiju kā svarīgu akadēmisko disciplīnu augstākajā izglītībā ainavu arhitektūrā. Ainavu un sociālās zinātnes kā akadēmiskās disciplīnas ir ar senu attīstības vēsturi, attiecīgi no 16. un 18. gadsimta. Ainavu sociologija savukārt ir jauns sociololoǵijas atzars, kas vēl attīstās. Pašlaik vēljoprojām nav viennozīmīgi skaidras robežas un definīcija ainavu socioloǵijas jēdzienam. Nozīmīgākā atšksirība strap sociologiju un ainavu socioloǵiju ir ainavas mērogs, kas ir nozīmīgs ainavu socioloǵijai. N̦emot vērā, ka mūsdienās augstākā izglītība paliek aizvien specializētāka, ir nozīmīgi iekḷaut ainavu sociologiju ainavu arhitektūras augstākajā izglītībā. 